\title{
Entrepreneurs of the Streets: an Analytical Work on the Street Food Vendors of Dhaka City
}

\author{
Ahmed Taneem Muzaffar (Corresponding author) \\ Department of Economics \\ East West University \\ 43, Mohakhali Commercial Area, Dhaka 1212, Bangladesh \\ Tel: 88- 1711-232-244Ｅ-mail: taneemm@yahoo.com \\ Iftekharul Huq \\ Department of Economics \\ East West University \\ 43, Mohakhali Commercial Area, Dhaka 1212, Bangladesh \\ Tel: 88-1911-489-811Ｅ-mail: nitol12@hotmail.com \\ Biva Arani Mallik \\ Department of Economics \\ East West University \\ 43, Mohakhali Commercial Area, Dhaka 1212, Bangladesh \\ E-mail: biva_12@hotmail.com
}

\begin{abstract}
Street food vending is a prevailing and distinctive part of a large informal sector in Dhaka city, the capital of Bangladesh. The paper attempts to gain insight into the business of street food vendors: highlight the problem areas and identify some key factors that positively affect their sales revenue. Using factor analysis as a tool, four major problem areas for the street food vendors have been identified. The problem areas are related to business operation, business knowledge, extortion, and product and production. Through regression analysis, it has been found that business experience, and initial capital is two key factors that positively affect sales revenue. Formal education, however, does not have any significant impact on business performance. The paper also comes to the conclusion that lack of security and problems in the supply of raw materials are two major problems as perceived by the vendors.
\end{abstract}

Keywords: Street food vendors, Informal sector, Food safety, Small business

\section{Introduction}

Street food vending is a prevailing and distinctive part of a large informal sector in Bangladesh. It is commonly viewed in public spaces particularly in the cities and distinctive in the sense that it provides a basic need to the urban inhabitants. The items made available by the street vendors comprise of a diverse range of selection, starting from small snacks such as biscuits, tea, nuts and phuchka/chotpoti (Note 1) to wholesome meals such as ruti-bhaji (Note 2) and rice. Each street food enterprise is generally small in size, requires relatively simple skills, basic facilities, and small amounts of capital. As such they hold tremendous potential for generating income and employment for the rapidly rising urban population of Dhaka city, the capital of Bangladesh. This paper is an attempt to gain an insight into the factors affecting the nature of the business. The specific objectives, we set forth, are to test some stylized facts about street food vending; how some key variables affect the sales revenue of the business and identify and explain the key impediments faced by the vendors.

Drawing from the definition quoted by Dardano (2003) we define street food as food prepared on the streets and ready-to-eat, or prepared at home and consumed on the streets without further preparation. The food items are sold by 
vendors and hawkers especially in streets and other similar public places. It is largely recognized that street foods play an important socio economic role in terms of employment potential, special income for women, and in serving the food at prices affordable to the lower and middle-income groups. It is also dubbed as the very essence of a country or region's tradition. It is believed to mirror the ways of ordinary people reflecting lifestyle, race, and religion (Wickware, 1998 quoted in Muzaffar, 1998).

The street food vending has largely been considered as part of the informal sector; and separate numbers specifically for street food vending is hard to find. One of the reasons why counting the number of vendors in informal food sector is a formidable task because many of the vendors are itinerant, moving one site to another. However, in an article by Allain (1991), it is found that in the Indonesian city of Bogor annual sales of street food amount to US\$67 million (quoted in Cohen, 1986) and in Malaysia US $\$ 2.2$ billion (quoted in Allain, 1988). Thus, street food vending plays a vital role for the economic planning and development of many towns.

\section{A Review of literature}

There exists ample discussion on street food vending in literature although a large portion of it is concentrated on the health and hygiene feature of this group. There are also some papers that concentrate on the nutrition aspects of street food vending and its ability to provide a basic need to the urban dwellers at affordable prices. Akin to this line of thought, Acho-Chi (2002) looked into the mobile food service practice in Kumba, Cameroon, in terms of its basic characteristics, the locational factors influencing its socio-spatial distribution, the critical success factors determining customer choices, and its impacts on the local environmental resources and quality of urban life.

Among those concentrating on health and hygiene, Muinde and Kuria (2005) point to the unstable and precarious of establishments of the street food vendors of Africa. They identify the lack of basic hygiene and sanitary practices both in the case of serving as well as preserving food in this sector. To that end the study emphasizes on the need for the establishment of street food centers by the city council, the training of street food vendors on hygiene, sanitation and the establishment of code of practice for the street food industry and the empowerment of Public Health Officers. Subratty, Beeharry, and Sun (2004) conducted a similar study in Mauritius and highlight the need for health education among food vendors.

In a report of FAO, Pan American Health Organization (PAHO), and Barbados National Standards Institution (BNSI) (2003) a comparison of health and hygiene standards practiced by street food vendors was carried out among seventeen English speaking Caribbean countries. It was found that although in varying levels, improper hygiene practices, lack of running water, improper storage of food etc. were prevailing in almost all the countries.

On a similar note, Nicolas et al. (2007) collected data on street vended food in western African countries to find the contamination mechanisms and suggest improvement pathways. They recommend the Food Safety Objective (FSO) concept developed by FAO and WHO to aid governments in elaborating guidance for street food production, vending and consumption.

A host of literature also exists focusing on the nutrition aspect of street foods. To sight an example of this, a profile of street food vending was conducted in Botswana by Ohiokpehai (2003) where the focus was on the content and nutritional impact of street food for people where some segments of the population rely almost entirely on street food vending for their everyday meals.

Von and Mahoane (2006) found that street food vendors in South Africa were capable of producing relatively safe food with low bacterial counts, although there was still a need for proper hygiene conditions and access to basic sanitary facilities.

Published literature in respect of identifying and a need for acknowledging the problems of entrepreneurs of street food vending in Dhaka city is scarce. Amin (1989) states that a large part of Dhaka city's economy goes unrecognized and referred it as the 'traditional sector' or informal sector, operating outside the incentive system offered by the state and its institutions. Wickware (1998) points out that the food vendors in informal sector are distinct from their official brethren only because their work status is more unstable, more vulnerable, and illegal (quoted in Muzaffar, 1998). Amin's (1989) work also provides a comparison between formal and informal sectors helping us identify some key features attributable to street food vending as well (Table 1).

\section{Research propositions}

Amin (1989) identifies that setting up a business in the informal sector may not require formal education. Since operating the food vending business in the streets demands simple skills, the perception is that the vendors do not need to have a high educational background in order for a better performance. Thus, we propose:

Proposition 1: Number of years spent in educational institution does not significantly affect the performance of the business (street food vending) in terms of raising sales revenue.

The presence of business acumen is important to run any form of enterprise. Experience helps develop the insight of 
doing business in an efficient manner. Although receiving formal education may not be very important in running the business in the streets, experience should be an influencing factor. Our proposal, therefore, is:

Proposition 2: Experience in terms of years doing the business significantly affects the sales revenue of food vendors.

The easy access to such a business, as stated in Amin (1989), is perhaps explained by the requirement of small amount of initial capital. However, starting with a higher initial capital is likely to ensure a better performance. Thus, we suggest the following proposition:

Proposition 3: The amount of initial capital plays a significant role in raising the sales revenue of the street food vendors.

Literature also suggests that the state of business in informal sector is characterized as unstable, vulnerable, and illegal (Amin, 1989; Wickware, 1998). Such attributes result in a sense of insecurity amongst the street food vendors. Not feeling secured, doing the business in the streets, acts as a major impediment and the next proposition is therefore:

Proposition 4: Lack of security affects significantly the overall problem in doing business as perceived by the vendors.

The food vending business in the streets of Dhaka can be viewed as competitive, labor intensive, requiring less advanced technology and a reliance on domestic inputs (Table 1). Access to raw materials to produce these nonstandard products tends to be relatively easy and smooth. This leads us to suggest:

Proposition 5: Supply of raw materials does not significantly affect the overall problem faced by the street food vendors.

\section{Method of analysis}

\subsection{Identification of problems and design of questionnaire}

In order to attain the research objectives we aimed at conducting a survey to collect primary data for analysis. The lack of detailed discussion in the context of Bangladesh in the published literature prompted us to gain a first hand knowledge from the field. One of our objectives was to identify the kinds of impediments that exist in this business as perceived by the vendors. Since the existing literature did not help us much in this regard, we decided to conduct a preliminary survey using a semi-structured questionnaire on street food vendors from three different places of Dhaka city in early May, 2008. The purpose was to list the major problems suggested from the entrepreneurs' point of view. A total of 35 vendors participated in this preliminary survey and they were asked to state top ten problems they face as an entrepreneur in this business. Following is the list of problems they identified as major ones:

What is important to note from the vendors' response is that hygiene (for example access to running water or proper sanitary facilities) and food safety (for example access to clean drinking water and problems relating to storage of food) is not identified as a major challenge for them (the food vendors). Perhaps there exists a lack of awareness from the vendors' side or this aspect is more of a concern for observers thinking of consumers' right to have safe food.

Using the information obtained from the preliminary survey, we created a structured questionnaire to carry out the investigation for analysis. The listed problems were used as scale items to execute a further attitudinal survey in order to test the research hypotheses. In addition to the 13 problems above, a variable of overall problem as perceived by the vendors was used as a scale item also (Table 2).

\subsection{Source and reliability of data}

The survey, using the structured questionnaire, took place in 10 different locations of Dhaka city where concentration of street food vendors is relatively high in late May and June, 2008. These places include bus, railway, and launch stations, parks, busy market places and other such public spaces. We received responses from 155 vendors of which only 5 were female entrepreneurs.

The respondents were asked to provide their opinion on the 14 scale items discussed above and they were processed through five point bi polar scale system. In the scale 5 and 4 indicate strongly agree and moderately agree respectively, while 3 indicates no comment, and 1 and 2 refer to strongly disagree and moderately disagree respectively. The 14 scale items were assessed for reliability using coefficient alpha. The reliability coefficient was 0.78 (Table 3 ) which exceeded the value of 0.70 , being consistent with the recommendation of Nunnally (1978).

\subsection{Tools of analysis}

With the collected data we primarily carried out two types of analysis using statistical software. These are factor analysis, using SPSS, to identify the key problems explaining the major impediments of doing the business and regression analysis, using EViews, to test the statements we hypothesized. The initial reliability test on the scale items ensures appropriateness of factor analysis (Cronbach's Alpha stands at 0.78). Other assessments of the suitability of the data for factor analysis also support the condition. For instance Nunnally (1978) recommends a 10 to 1 ratio that is 10 cases for each item to be factor analyzed. Our sample size of 155 satisfies the minimum requirement of 140 cases (since there are 14 items). Two major statistical measures, generated by SPSS also support the appropriateness of factor 
analysis on the data. Both KMO index which is above 0.6 and Bartlett's test of sphericity which is significant suggest the minimum value for a good factor analysis (Table 4).

\section{Discussion on findings}

\subsection{Descriptive statistics}

The research puts emphasis on identifying the caveats as expressed by the street food vendors in the city of Dhaka. Table 5 summarizes some of the demographic features of the sample. As mentioned earlier all vendors willing to be interviewed in the survey were predominantly male. The respondents tend to fall into the middle aged group, average age standing at about 34 years. Evidence also reveals a poor educational background of the respondents. The mean formal education is at 3.75 years reflecting the fact that most of them could not even complete their primary education. The sample is comprised of a considerable amount of married male vendors, percentage of which is $72 \%$.

The average length of activity of the vendors is close to 7 years and on average they work around 12 hours per day (Table 6). The mean value for number of days worked in a month show that they take very few days off.

The average monthly income of a food vendor appears to be Taka 5647 whereas average monthly expenditure is Taka 5939 (Figure 1). This puts them at the risk of becoming a net borrower. However, it may be noted that they are not always the sole earners of the family and may get support from other earning family members. Among the overall expenditure, spending on food dominates at $60 \%$, followed by rent at $15 \%$. Hence bare minimum living costs eat up the majority of their income. The remainder $25 \%$ consists of all other expenses such as those on clothing, remittance, health, education, traveling and expenditure on cigarettes.

The composition of overall expenditure shows that apart from expenditure on cigarettes, all of the spending fall under the bracket of necessary expenditure leaving them very little room, if at all, to enjoy the perks of city life.

\subsection{Results of factor analysis}

As stated earlier, the first step to our analysis is to identify the impediments faced by street food vendors in conducting their daily business. Having realized 13 problems, we try to group them using the method of factor analysis. The result of the factor analysis is shown in Table 7. We see that four factors emerge from the factor analysis of problems faced by the vendors. The extraction of the constructs, we chose, was based on the factors having eigen value above 1 and total accumulated variance of the factors stands at around $60 \%$. Among the four factors, business operation related factor contributes most significantly with the eigenvalue of 3.387 and it explains $23.23 \%$ of the variance. The problem relating to business knowledge becomes the second highest contributing factor with the eigenvalue of 2.178 . The remaining two are extortion related and product and production related factors.

Table 8 illustrates the loadings of scale items in each of the factors. Some of the items are dropped from each factor because they either have low loading values, or have negative impact on reliability, or do not have a deep relationship with the factor. Law and regulation becomes the highest loading item in explaining the business operation related factor. Bad weather, lack of security and supply of raw materials are the other three items with relatively high loadings. In factor two, lack of business knowledge turns out to be the variable with greater loading relative to lack of appropriate skill. Extortion related factor is addressing the significance of extortion fee by local "mastans" (extortionists). And lastly, high cost of production is identified as the highest loading item for factor explaining the problem relating to product and production. The reliability coefficients of all factors are also shown in Table 8. Not all of these, however, show values higher than the threshold level.

The above grouping might enable policy makers to effectively identify areas of intervention when they integrate this sector into urban planning.

\subsection{Results from regression analysis}

In the second part of our analysis we attempt to clarify the propositions stated earlier with the help of two regression models. The two dependent variables stated are 'sales revenue' and 'overall problems as perceived by street vendors' as all the propositions seek to explain these two factors.

The first regression equation is designed to explain sales revenue of street food vendors through years of formal education, experience and initial capital.

$$
\text { SALESREV }=683.2528+53.29855 \text { EDUYR }+1.941025 \text { EXPR }+0.032246 \text { INICAP }(1)
$$

$\begin{array}{lllcc}\text { Std. Error } & (178.3700) & (27.52442) & (0.896845) & (0.009991) \\ \text { t-value } & (3.830536) & (1.936410) & (2.164281) & (3.227679) \\ \text { Sig. Level } & (0.0002) & (0.0552) & (0.0324) & (0.0016)\end{array}$

$\mathrm{R}^{2}=0.14 \quad$ Adjusted $\mathrm{R}^{2}=0.12$

Where, 
SALESREV $=$ Daily sales revenue in Taka

EDUYR $=$ Educational background in terms of years spent in school

EXPR $=$ Experience in terms of number of months doing the business

INICAP $=$ Initial capital at the start of the business in Taka.

The estimated equation above helps us to reach the following conclusions:

First, the coefficient of educational background in terms of years spent in school is positive but not significant at 5\% level. Thus we deduce that years spent in education does not significantly affect sales revenue generated by street food vendors. This allows us to not reject our first proposition.

Second, the coefficient to experience in business is positive and significant at $5 \%$ level, allowing us to not reject our second proposition that 'experience in terms of years doing the business significantly affects the sales revenue of food vendors'. As experience enables vendors to gather insight and knowledge that holds more purpose to them than formal education would.

Finally, the coefficient to initial capital is also positive and significant. As per proposition 3, we observe that the amount of initial capital plays a significant role in raising the sales revenue of the street food vendors.

The second regression model is explaining the overall problem as perceived by the vendors through lack of security and problem related to supply of raw materials.

$$
\text { OVRPROB }=2.162722+0.294919 \text { PROBE }+0.203993 \text { PROBJ }
$$

$\begin{array}{lllc}\text { Std. Error } & (0.183253) & (0.052999) & (0.061771) \\ \text { t-value } & (11.80183) & (5.564632) & (3.302425) \\ \text { Sig. Level } & (0.0000) & (0.0000) & (0.0013) \\ R^{2}=0.409 & \text { Adjusted } R^{2}=0.398 & \end{array}$

Where,

OVRPROB $=$ Overall problem as perceived by the street food vendors

PROBE $=$ Problem of lack of security

PROBJ $=$ Problem of supply of raw materials.

As illustrated by the equation above, the overall problem as perceived by street food vendors can largely (39\%) be explained by lack of security and supply of raw materials.

The coefficients to both the problems are positive and significant indicating that both of them positively affect the overall problem as perceived by the street food vendors. We would therefore not reject proposition four and reject proposition five.

\section{Conclusion and observations for policy makers}

The street food vendors play an important role in Dhaka city. At root, it creates numerous jobs and absorbs a rising proportion of the unemployed workers. Recognition of this sector and proper assistance should significantly improve their performance in the business. Through the result of our study we identify four major areas of problems that street food vendors face today. These problem areas emerge as per the perception of street food vendors themselves. The four problem areas are relating to: (i) business operation, (ii) business knowledge, (iii) extortion related, and (iv) product and production.

It was also found, that for this sector experience holds more importance than formal education. As operating the food vending business in the streets demands simple skills, the perception is that high levels of education is not necessary for better performance in the business. Such perception has been confirmed by the estimated model. Thus the sector proves to be a potential area to absorb the massive unskilled/semi skilled unemployed population. It was found that experience and initial capital significantly and positively affect sales revenue.

The insignificance of formal education holds an interesting insight for policy makers when they plan for after work classes targeting the adult or employed children. In order to attract this group it is important to make formal education seem worthwhile to them. If Non Governmental Organizations (NGOs) and other institutions incorporate skill development (in relevant areas) into their curriculum, it might create an incentive for the street food vendors to avail formal education.

As for the overall perceived problems of the vendors, they identify lack of security and access to raw materials as the dominant problems. These identified problem areas might enable policy makers to efficiently recognize caveats for intervention when they seek to do so. 


\section{Acknowledgement}

The authors are grateful to Dr. Syed Shahadat Hossain, Professor of Statistics, Institute of Statistical Research and Training, University of Dhaka, Bangladesh for his valuable guidance.

\section{References}

Acho-Chi, C. (2002). The mobile street food service practice in the urban economy of Kumba, Cameroon. Singapore Journal of Tropical Geography, 23 (2), pp. 131-148. [Online] Available: www.geo.ntnu.edu.tw/faculty/moise/words/information/economy/retail\%20geography/r24.pdf

Allain, A. (1988). Street foods, the role and needs of consumers. Expert consultation on street foods. Jogjakarta, Indonesia, FAO.

Amin, A. T. M. N. (1989). Dhaka: Past, Present, Future, the Asiatic Society of Bangladesh, Dhaka, Bangladesh.

Cohen, M. (1986). The influence of the street food trade on women and child health. In D.B. Jelliffe \& E.F.P, Jelliffe, eds. Advances in international maternal and child health. Vol. 6, Oxford, Clarendon Press.

Dardano, Carmen (2003). Caribbean regional working group on street food vendors, Report of FAO, PAHO and BNSI. [Online] Available: ftp://ftp.fao.org/es/esn/food/carribean_report.pdf

Muinde, O.K. and Kuria, E. (2005). Hygienic and sanitary practices of vendors of street foods in Nairobi, Kenya. African Journal of Food Agriculture Nutrition and Development, 5.

[Online] Available: http://www.ajfand.net/Issue-VIIIfiles/pdfs/AJFAND\%20Vol\%205\%20No\%201\%20Peer\%20Reviewe\%20Article\%20N o\%207.pdf. retrieved on 04.04.2008.

Muzaffar, A., T., (1998). An Economic Survey of the Informal Sector in Sutrapur Thana, Dhaka, Unpublished Research Paper, North South University, Dhaka, Bangladesh.

Nicolas, B., Razack, B.A., Yollande, I., Aly, S., Tidiane, O.C.A., Philippe, N.A., Comlan, D.S. and Sababenedjo, T.A. (2007). Street-vended foods improvement: Contamination mechanisms and application of food safety objective strategy: Critical review, Pakistan Journal of Nutrition, 6 (1): 1-10.

Nunnally, J. O. (1978). Psychometric Theory. New York. McGraw Hill.

Ohiokpehai, O. (2003). Nutritional aspects of street foods in Botswana. Pakistan Journal of Nutrition, 2: 76-81.

Subratty, A.H., Beeharry, P. and Chan Sun, M. (2004). A survey of hygiene practices among food vendors in rural areas in Mauritius. Nutrition \& Food Science, Vol. 34, No. 5, Emerald Group Publishing Limited.

Von, H.A. and Makhoane, F.M. (2006). Improving street food vending in South Africa: Achievements and lessons learned. International Journal of Food Microbiology, 111: 89-92.

Wickware, Dana, (1998). The Shadow Economy, Urban Age. The Global City Magazine, Vol. 6, No. 1, Summer, p. 5-9.

Winarno, F.G. and Allain, A. (1991). Street foods in developing countries: Lessons from Asia, Food, Nutrition and Agriculture, Issue 1.

[Online] Available: http://www.fao.org/docrep/u3550t/u3550t0a.htm\#TopOfPage

\section{Notes}

Note 1. A popular spicy snack in the sub-continent.

Note 2. A bread based meal common for breakfast. 
Table 1. Some attributes of informal sector businesses

\begin{tabular}{|c|c|}
\hline Market Structure & Characteristics of Informal Sector Businesses \\
\hline \multirow[t]{3}{*}{ Output Market } & No barriers to entry \\
\hline & Competitive firms \\
\hline & Nonstandard, unregistered products \\
\hline \multirow[t]{4}{*}{ Factor Market } & Easy access \\
\hline & Competitive \\
\hline & No compliance to labor legislation \\
\hline & No access to credit, self financed bodies \\
\hline \multirow[t]{4}{*}{ Technology } & Adapted traditional technology \\
\hline & Relatively labor intensive \\
\hline & Domestic inputs \\
\hline & May not need formal education \\
\hline \multirow[t]{7}{*}{ Industrial organization } & Small, unincorporated \\
\hline & Unregistered \\
\hline & Small scale operation \\
\hline & Non-remunerated family works \\
\hline & Seasonal part time occupation \\
\hline & Generalized tax evasion \\
\hline & Unlimited risks \\
\hline
\end{tabular}

Source: Adapted from Amin, 1989.

Table 2. List of variables used as scale items

1. PROBA $=$ Lack of business knowledge

2. $\mathrm{PROBB}=$ Lack of appropriate skill

3. $\mathrm{PROBC}=$ Lack of capital

4. $\mathrm{PROBD}=$ Lack of manpower

5. $\mathrm{PROBE}=$ Lack of security

6. $\mathrm{PROBF}=$ Laws and regulation related problem

7. $\mathrm{PROBG}=$ Police harassment

8. $\mathrm{PROBH}=$ Extortion fee by local 'mastans' (extortionists)

9. PROBI $=$ Political instability

10. PROBJ $=$ Problem with supply of raw materials

11. $\mathrm{PROBK}=$ Problem of high cost of production

12. $\mathrm{PROBL}=\mathrm{Bad}$ weather

13. $\mathrm{PROBM}=$ Perishable product

14. OVRPROB $=$ Overall problem in doing the business

Source: Preliminary field survey, May, 2008 
Table 3. Reliability statistics

\begin{tabular}{cc}
\hline Cronbach's Alpha & Number of items \\
\hline 0.78 & 14
\end{tabular}

Source: SPSS output from field survey, May and June, 2008.

Table 4. KMO and Bartlett's Test result on problems

\begin{tabular}{ccc}
\hline \multicolumn{2}{c}{ Kaiser-Meyer-Olkin Measure of Sampling Adequacy } & .686 \\
\hline Bartlett's Test of Sphericity & Approx. Chi-Square & 252.582 \\
\hline & Df & 78 \\
\hline
\end{tabular}

Source: SPSS output from field survey, May and June, 2008.

Table 5. Some demographic information of the sample

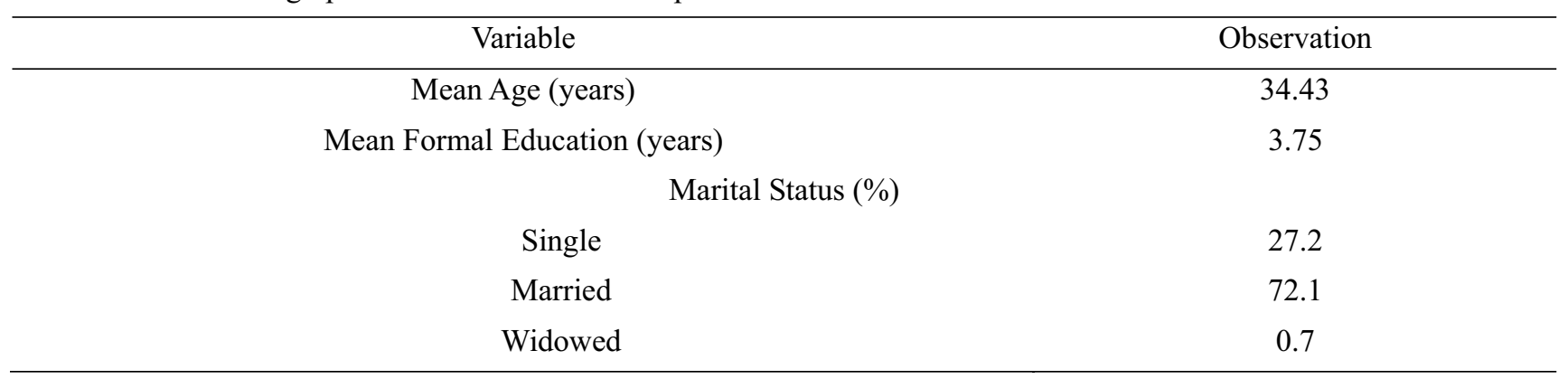

Source: Field Survey, May and June, 2008.

Table 6. Duration of activity and average work load

\begin{tabular}{ll}
\hline Item & Mean \\
\hline Length of activity (months) & 80.24 \\
Days / Month & 28.17 \\
Hrs / Day & 12.16 \\
\hline
\end{tabular}

Source: Field Survey, May and June, 2008.

Table 7. Factor analysis (Varimax) of the problems faced by the street food vendors

\begin{tabular}{lccc}
\hline \multicolumn{1}{c}{ Factor } & Eigen Value & $\begin{array}{c}\text { Explained } \\
\text { Variance }\end{array}$ & Accumulated Variance \\
\hline Business operation related & 3.387 & 23.230 & 23.230 \\
\hline Business knowledge related & 2.178 & 13.083 & 36.313 \\
\hline Extortion related & 1.199 & 12.190 & 48.503 \\
\hline Product and production related & 1.086 & 11.877 & 60.380 \\
\hline
\end{tabular}

Source: SPSS output from Field Survey, May and June, 2008.

Notes: Extraction Method: Principal Component Analysis. Rotation Method: Varimax with Kaiser Normalization. 
Table 8. Loading of items within each factor explaining problem

\begin{tabular}{ccc}
\hline Factor & Loading & Reliability \\
\hline Business operation related & & 0.75 \\
Laws and regulation & 0.790 & \\
Bad weather & 0.740 & \\
Lack of security & 0.737 & 0.71 \\
Supply of raw materials & 0.702 & \\
\hline Business knowledge related & & \\
Lack of business knowledge & 0.795 & \\
Lack of appropriate skill & 0.751 & \\
Extortion related & & \\
Extortion fee by local mastans & 0.759 & \\
Police harassment & 0.696 & \\
\hline Product and production related & 0.828 & \\
High cost of production & 0.677 & \\
Perishable product & &
\end{tabular}

Source: SPSS output from Field Survey, May and June, 2008.

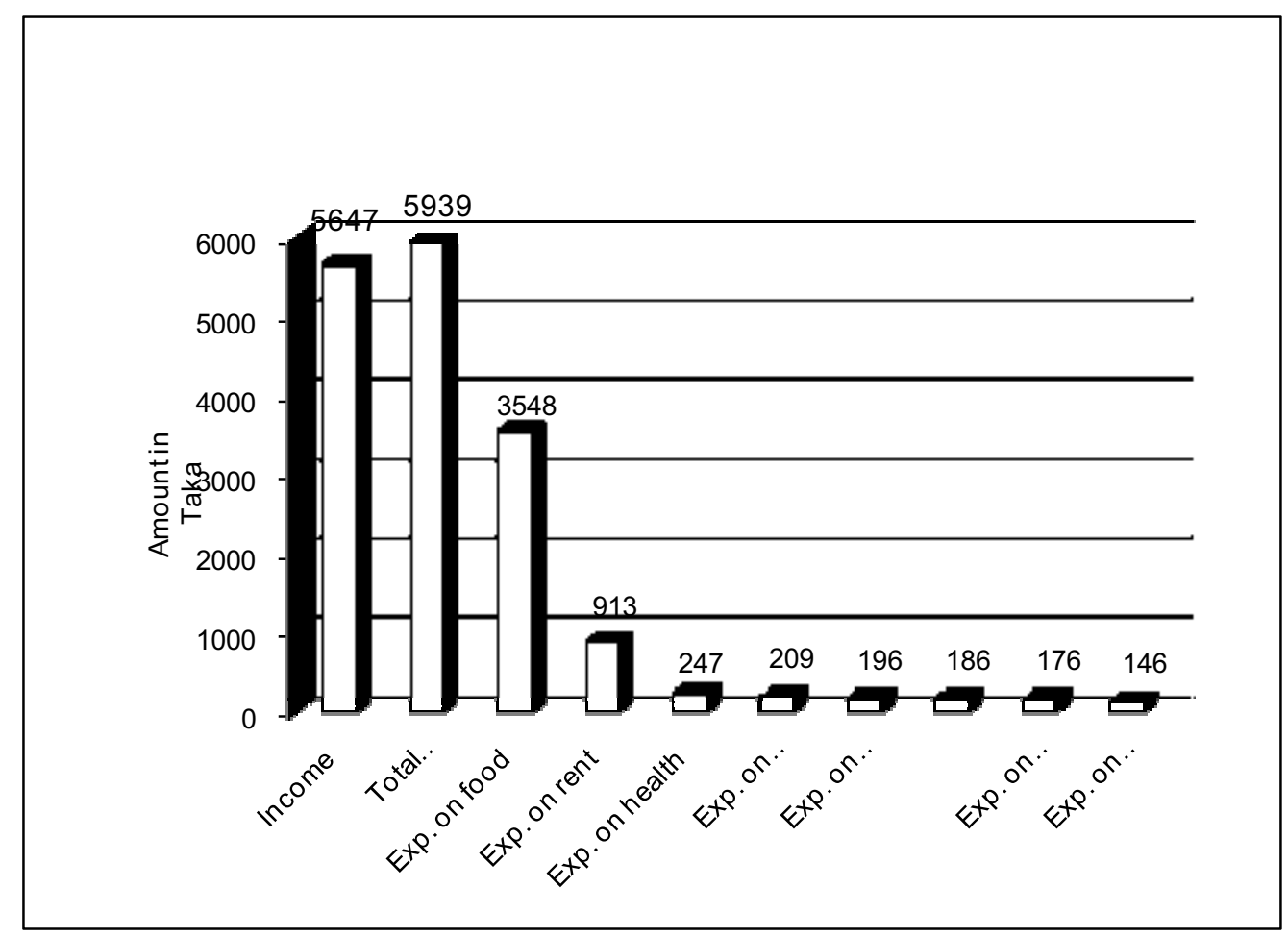

Figure 1. Monthly income and expenditure pattern

Source: Field Survey, May and June, 2008. 